\section{Nitrous oxide does not increase vomiting in children after myringotomy}

William M. Splinter MD FRCPC,

David J. Roberts MD FRCPC,

Elliot J. Rhine MD FRCPC, Helen B. MacNeill MD FRCPC, Lydia Komocar RN
The aim of this study was to establish whether nitrous oxide has a clinically important effect on postoperative vomiting in children after myringotomy. We studied 320 healthy children of ages 0.5-13 yr undergoing elective myringotomy and tube insertion. Induction and maintenance of anaesthesia were randomized to inhalation with either $70 \% \mathrm{~N}_{2} \mathrm{O} / 30 \% \mathrm{O}_{2} /$ halothane or $100 \% \mathrm{O}_{2} /$ halothane. Surgical technique and postoperative management were not influenced by this study. Vomiting in the recovery room (PAR) and Day Care Surgical Unit (DCSU) was recorded by nurses unaware of the anaesthetic technique. Parents were contacted 24-48 hr afier surgery to ascertain the incidence of vomiting after discharge. The groups were similar with respect to demographic data, except that the anaesthesia time was greater among the 158 patients in the $\mathrm{N}_{2} \mathrm{O}$-treated group (11 \pm 4 vs $12 \pm 4$ min, mean $\pm S D$ ). The incidence of vomiting was $13 \%$ in both groups. Most of the 42 patients that had emesis only vomited once or twice. The incidence of vomiting was not altered by sex (13\% vs $13 \%)$ or duration of anaesthesia. The incidence of vomiting increased with increasing age. The children aged less than $3 y r$ vomited $4 \%$ of the time, thase aged 3-5 vomited $11 \%$ of the time, thase aged 6-8 yr vomited $17 \%$ of the time, while the incidence of vomiting among thase aged 9-13 yr was 31\%. Vomiting prolonged the postoperative hospital stay from 75 to $92 \mathrm{~min}, P<0.001$, ANOVA. In summary, we have been unable to demonstrate that $\mathrm{N}_{2} \mathrm{O}$ induces vomiting by children after a brief general anaesthetic for myringotomy.

\section{Key words}

ANAESTHESIA: paediatric;

ANAESTHETICS, GASES: nitrous oxide;

VOMITING: nitrous oxide, postoperative.

From the Department of Anaesthesia, Children's Hospital of Eastern Ontario, and The University of Ottawa, Ottawa,

Ontario, Canada.

Address correspondence to: Dr. William Splinter,

Department of Anaesthesia, Children's Hospital of Eastern

Ontario, 401 Smyth Rd., Ottawa, Ontario, Canada K1H 8Ll.

Presented in part at the 1991 Annual Meeting of the

American Society of Anesthesiologists, San Francisco, USA.

Accepted for publication 27th November, 1994.
Cette étude a pour but d'établir si le protoxyde d'azote des vomissements chez les enfants après une myringotomie. L'étude porte sur 320 enfants bien portants âgés de 0,5 à 13 ans soumis à une myringotomie programmée avec insertion de tube. L'induction et l'entretien de l'anesthésie sont randomisés pour l'inhalation soit de $\mathrm{N}_{2} \mathrm{O} 70 \% / \mathrm{O}_{2} 30 \%$ avec halothane, soit d'O $100 \%$ avec halothane. Cette étude nïnfluence ni la technique chirurgicale ni la gestion postopératoire. Les vomissements à la salle de réveil et à l'unité chirurgicale de jour sont enregistrés par des infirmières ignorant la technique utilisée. Les parents sont contactés 24-48 après la chirurgie pour évaluer lincidence des vomissements. Les groupes sont comparables au regard des données démographiques, à l'exception du fait que la durée de l'anesthésie est plus grande dans le groupe $\mathrm{N}_{2} \mathrm{O}$ (moyenne $\pm S D: 11 \pm 4$ vs $12 \pm 4$ ). Lincidence des vomissements n'est modifiée ni par le sexe (13\% vs 13\%) ni la durée de l'anesthésie. Lincidence des vomissements augmente avec l'âge. Les enfants de moins de trois ans vomissent $4 \%$ du temps, ceux de 3-5 ans vomissent $11 \%$ du temps, alors que lincidence des vomissements est de 31\% chez les enfants de 9-13 ans. Les vomissements prolongent la durée du séjour haspitalier de 75 à 92 min, $P<0,001$ (ANOVA). En résumé, nous n'avons pu démontrer que le $\mathrm{N}_{2} \mathrm{O}$ provoque des vomissements après la courte anesthésie générale administrée pour la myringotomie.

Vomiting after general anaesthesia in children is common and may result in considerable postoperative morbidity. This vomiting is of multifactorial aetiology of which nitrous oxide is a possible contributing factor. Nitrous oxide may induce vomiting by causing bowel distension, decreasing gastric motility, increasing middle ear pressure or interacting with endogenous opioid receptors. ${ }^{1-3}$

Among adults undergoing minor gynaecological surgery, as little as a 10-14 min exposure to $\mathrm{N}_{2} \mathrm{O}_{2}$ has been associated with increased vomiting. ${ }^{3}$ Overall, the results of adult investigations have been controversial. Both an emetic ${ }^{2-5}$ and lack of effect ${ }^{6-9}$ have been reported. There have been two paediatric studies. Pandit et al. failed to demonstrate a difference in vomiting after tonsillectomy (62\% vs $76 \%) .^{6}$ In another study of 104 children, nitrous oxide increased vomiting after myringotomy from $4 \%$ to 
TABLE I Demographic data and recovery times

\begin{tabular}{llllll}
\hline & $n$ & $\begin{array}{l}\text { Age } \\
(y r)\end{array}$ & $\begin{array}{l}\text { Weight } \\
(\mathrm{kg})\end{array}$ & $\begin{array}{l}\text { Anaesthesia time } \\
(\text { min })\end{array}$ & $\begin{array}{l}\text { PAR }+ \text { DCSU Stay } \\
(\text { min })\end{array}$ \\
\hline${\mathrm{Non} \mathrm{N}_{2} \mathrm{O}} \mathrm{O}$ & 162 & $4.9 \pm 2.9$ & $20 \pm 9$ & $11 \pm 4^{*}$ & $78 \pm 19$ \\
\hline
\end{tabular}

Mean $\pm \mathrm{SD}, * P<0.05$, ANOVA.

TABLE II Effect of age on emesis

\begin{tabular}{lrll}
\hline Age $(y r)$ & $n$ & Group & \% Vomit \\
\hline $0.5-2.9$ & 92 & I & 4 \\
$3.0-5.9$ & 124 & II & 11 \\
$6.0-8.9$ & 75 & III & $17^{*}$ \\
$9.0-12.9$ & 29 & IV & $31 \dagger$ \\
\hline
\end{tabular}

${ }^{*} P<0.05$, III vs I; $\nmid P<0.05$, IV vs I or II, Chi-square analysis with Bonferroni correction factor.

$21 \%, P<0.05 .^{4}$ The aim of the current study was to establish whether nitrous oxide has a clinically important effect on postoperative vomiting in children.

\footnotetext{
Methods

With Hospital Ethics Committee approval and parental consent we studied 320 healthy (ASA physical status I-II) children aged $0.5-13$ yr undergoing elective myringotomy and tube insertion. Children were excluded if they had gastrointestinal disease or an allergy to one of the study drugs. Subjects did not receive premedication. After establishing routine monitoring, induction and maintenance of anaesthesia was randomized to inhalation of either $70 \% \mathrm{~N}_{2} \mathrm{O} / 30 \% \mathrm{O}_{2} /$ halothane or $100 \% \mathrm{O}_{2} /$ halothane. Surgical technique and postoperative management were not affected by this study, which included acetaminophen 10 $\mathrm{mg} \cdot \mathrm{kg}^{-1}$ po for pain relief. The frequency of vomiting in the recovery room (PAR) and Day Care Surgical Unit (DCSU) was recorded by nurses unaware of the anaesthetic technique. Parents were contacted $24-48 \mathrm{hr}$ after surgery to determine the incidence of vomiting after discharge and to confirm the incidence of DCSU vomiting.

Data were compared with ANOVA and Chi-square analysis, where appropriate. The acceptable alpha error was 0.05 with a Bonferroni correction factor when multiple comparisons were performed. For the purpose of sample size determination, the $\mathrm{N}_{2} \mathrm{O}$ group was predicted to have greater or similar incidence of vomiting when compared to the non- $\mathrm{N}_{2} \mathrm{O}$ group. The predicted incidences of vomiting were $16 \%$ and $7 \%$ and the power of the study was $80 \%$.
}

\section{Results}

The groups were similar with respect to demographic data, except that the anaesthesia time was one minute longer among the $\mathrm{N}_{2} \mathrm{O}$-treated subjects (Table I). Stay in the PAR and DCSU was not influenced by $\mathrm{N}_{2} \mathrm{O}$ exposure (Table I). The incidence of vomiting was $13 \%$ in both the $\mathrm{N}_{2} \mathrm{O}$ and non- $\mathrm{N}_{2} \mathrm{O}$ group. Most of the 42 patients that had emesis only vomited once or twice, but seven patients vomited on three occasions, one patient vomited four times and another ten times. The incidence of vomiting was $13 \%$ for both boys and girls. The duration of anaesthesia was $12 \pm 4$ and $11 \pm 4$ min among the subjects that did and did not vomit, respectively. Age had an effect on vomiting (Table II). Patients who vomited had an increased postoperative hospital stay, $75 \pm$ 15 vs $92 \pm 25 \mathrm{~min}$, mean $\pm \mathrm{SD}, P<0.001$, ANOVA.

\section{Discussion}

A brief 10-15-minute exposure to nitrous oxide did not affect vomiting after myringotomy in children. The observed overall rate of vomiting was similar to the $12 \%$ incidence observed by Wilson and Fell. ${ }^{4}$ Unlike Wilson et al., the current study, which has greater power, did not demonstrate that $\mathrm{N}_{2} \mathrm{O}$ induces vomiting after myringotomy in children. The results of Rowley and Brown's ${ }^{10}$ study, wherein the observed incidence of vomiting was $27 \%$, are not comparable with the current study because they did not control anaesthetic technique and premedication.

The present study's results differ from most adult studies in which $\mathrm{N}_{2} \mathrm{O}$ increased postoperative vomiting. " There have been controversial opinions of the relevance and analysis of these adult investigations. ${ }^{11,12}$ Conflicting results exist for a variety of reasons. Many investigations lack the power to conclude that $\mathrm{N}_{2} \mathrm{O}$ has no effect on vomiting. One theoretical reason is that $\mathrm{N}_{2} \mathrm{O}$ may have a relatively specific emetic effect. For example, the increased vomiting in adults is typically observed among female subjects exposed to opioids or procedures involving bowel motility. Investigations not specifically involving these subpopulations have been unable to establish a clinically relevant increased incidence of vomiting due to $\mathrm{N}_{2} \mathrm{O}$. Finally, the peripheral effects of $\mathrm{N}_{2} \mathrm{O}$ include distension of the gastrointestinal tract and increased mid- 
dle ear pressure. Both may have an emetic effect, but require a prolonged exposure to $\mathrm{N}_{2} \mathrm{O}$ in order to occur. Both of these peripheral effects should not have influenced our subjects because myringotomy would eliminate any alteration of the middle ear pressure and a brief exposure to $\mathrm{N}_{2} \mathrm{O}$ would have a minimal effect on bowel distension.

Vomiting may have added to the cost-of-care. Valuable nursing time was expended during the treatment of vomiting and during the extended in-hospital care of the patients that vomited. ${ }^{13}$

The observed effect of age on postoperative emesis has been previously reported, ${ }^{14,15}$ but its aetiology is unknown. Similar to Felts et al. ${ }^{2}$ we were unable to demonstrate that duration of anaesthesia had an effect on post-anaesthesia emesis.

In conclusion, we were unable to demonstrate that $\mathrm{N}_{2} \mathrm{O}$ altered the incidence of vomiting after general anaesthesia for myringotomy in children.

\section{Acknowledgements}

We would like to thank our colleagues in the Department of Otolaryngology for their cooperation and support during this investigation.

\section{References}

1 Scheinen B, Lindgren $L$, Scheinin TM. Peroperative nitrous oxide delays bowel function after colonic surgery. $\mathrm{Br}$ J Anaesth 1990; 64: 154-8.

2 Felts JA, Poler SM, Spitznagel EL. Nitrous oxide, nausea, and vomiting after outpatient gynecologic surgery. J Clin Anesth 1990; 2: 168-71.

3 Melnick $B M$, Johnson LS. Effects of eliminating nitrous oxide in outpatient anesthesia. Anesthesiology 1987; 67: 982-4.

4 Wilson IG, Fell D. Nitrous oxide and postoperative vomiting in children undergoing myringotomy as a day case. Paediatric Anaesthesia 1993; 3: 283-5.

5 Lonie DS, Harper NJN. Nitrous oxide anaesthesia and vomiting. The effect of nitrous oxide anaesthesia on the incidence of vomiting following gynaecological laparoscopy. Anaesthesia 1986; 41: 703-7.

6 Pandit U, Pryn S, Randel G, Levy L, Lewis I. Nitrous oxide does not increase postoperative nausea/vomiting in pediatric outpatients undergoing tonsillectomyadenoidectomy. Anesthesiology 1990; 73: A1245.

7 Muir JJ, Warner MA, Offord KP, Buck CF, Harper JV, Kunkel SE. Role of nitrous oxide and other factors in postoperative nausea and vomiting: a randomized and blinded prospective study. Anesthesiology 1987; 66: 513-8.

8 Sukhani $R$, Lurie J, Jabamoni R. Propofol for ambulatory gynecological laparoscopy: does omission of nitrous oxide alter postoperative emetic sequelae and recovery? Anesth Analg 1994; 78: 831-5.

9 Kortilla $K$, Hovorka J, Erkola $O$. Nitrous oxide does not increase the incidence of nausea and vomiting after isoflurane anesthesia. Anesth Analg 1987; 66: 761-5.

10 Rowley MP, Brown TCK. Postoperative vomiting in children. Anaesth Intensive Care 1982; 10: 309-13.

11 Hartung $J$. Nitrous oxide - it's enough to make you vomit (Letter). Anesthesiology 1993; 78: 403-5.

12 Watcha $M F$, White $P F$. Nitrous oxide - it's enough to make you vomit (Letter). Anesthesiology 1993; 78: 406.

13 Carroll NV, Miederhoff PA, Cox FM, Hirsch JD. Costs incurred by outpatient surgical centers in managing postoperative nausea and vomiting. J Clin Anesth 1994; 6: 364-9.

14 Cohen MM, Cameron CC, Duncan PG. Pediatric anesthesia morbidity and mortality in the perioperative period. Anesth Analg 1990; 70: 160-7.

15 Tan SGM, Hay HA, Cunliffe $M$. An audit of pain and vomiting in paediatric day case surgery. Paediatric Anaesthesia 1994; 4: 105-9. 